\title{
The Unfair Commercial Practices Directive: A Law and Economics Perspective
}

Fernando Gómez Pomar Universitat Pompeu Fabra

330 


\begin{abstract}
Directive 2005/29 on unfair commercial practices constitutes an ambitious attempt at building a general regulatory framework for firm actions towards consumer in the marketplace. The declared objectives of the Directive, namely consumer protection and eliminating barriers for the internal market, do not seem to provide enough support for such an overreaching legal intervention. The paper explores whether other rationales can justify the new rules and critically examines the scope and the tools to determine unfairness in commercial practices.

From an efficiency perspective, Directive 2005/29, although not devoid of merit and interesting solutions, is lacking both in terms of over-optimism in regulating practices that differ widely across markets for a whole range of goods and services, and disregarding several factors that greatly affect the necessary cost-benefit analysis for the major regulatory options.
\end{abstract}

\title{
Summary
}

\section{Introduction}

2. The plausible goals and organizing principles in regulating commercial practices

2.1. Efficiency in $b 2 c$ transactions

2.2. The redistributive ideal

2.3. The market manipulation theory

2.4. Removing barriers to trade with consumers across borders

3. The efficiency of the scope of Directive 2005/29

4. Setting the test for unfairness

5. Conclusion

6. References 


\section{Introduction}

Among the pieces of European legislation directly affecting, at least through more or less traditional instruments of Private Law, how markets operate, we should count, as one of the most significant, the recent Directive 2005/29/EC of the European Parliament and of the Council concerning unfair business-to-consumer commercial practices in the internal market (Directive 2005/29). The confessed goal of the Directive is twofold ${ }^{1}$ : to harmonize the existing -or nonexisting, in some cases- and diverging national rules on unfair commercial practices, so as to improve the smooth and unencumbered functioning of the European internal market in goods and services, and to achieve a high level of consumer protection vis-à-vis commercial practices by firms capable of harming the economic interests of consumers. The Directive, however, though not all-encompassing of the entire area of regulating business conduct towards consumers ${ }^{2}$, is notably ambitious and far-reaching in this field ${ }^{3}$, and relates directly or indirectly to many existing European rules on advertising and consumer protection in contractual relationships.

In this paper I try to offer a tentative analysis of the major implications and consequences of the new Directive, and to point out several shortcomings of the new legislation when viewed through the lenses of economic analysis. Some of these drawbacks become particularly apparent when one looks at the substantive market imperfections that may afflict consumer markets generally, and the regulatory alternatives that Governments have at their disposal to enhance social welfare in those markets, specially the informational failures that economists tend to identify as the major rationales for legal activism in consumer markets ${ }^{4}$. In this respect, it should be made clear from the start that the analysis would essentially be an efficiency analysis, or, if one prefers, a preliminary and general cost-benefit analysis of the legal policy choices embodied in

\footnotetext{
1 Art. 1 Dir 2005/29.

2 Dir 2005/29 excludes from its scope business-to-business transactions and actions [art. 3.1 and recital (7)], a fundamental exclusionary choice which I will not directly discuss in length in this paper. This choice has been criticised on legal policy grounds: J. STUYCK, E. TERRYN, and T. VAN DYCK, 'La proposition de directive "pratiques commerciales déloyales": quel marché unique pour le consommateur?' (2003) Revue européene de droit de la consummation 239, 259; A. BEATER, 'Europäisches Recht gegen unlauteren Wettbewerb- Ansatzpunkte, Grundlagen, Entwicklung, Erfoderlichkeit' (2003) ZEuP 11, 46. Others, have pointed out that fairness in dealing and transacting is also an issue in commercial relationships between traders, though significant modifying factors are typically present. Transactions are usually not discrete, but continuous, or repeated, and thus reputation plays a larger role in this area, and framework agreements, with or without legal force, tend to be present to structure future deals, thus making legal rules more interfering with private decision-making than in the business-toconsumer typical interaction: H. CoLLINS, 'EC Regulation of Unfair Commercial Practices', in H. ColLINS (editor) The Forthcoming EC Directive on Unfair Commercial Practices (The Hague/London/New York: Kluwer Law International, 2003) 1, 3.

3 C. Busch, 'Ein europäischer Rechtsrahmen für das Lauterkeitsrecht? Der Vorschlag der Europäischen Kommission für eine Richtlinie über unlautere Geschäftspraktiken’ (2004) European Legal Forum 91, 98.

4 See G. Hadfield, R. Howse, and M. Trebilcock, 'Information-Based Principles for Rethinking Consumer Protection Policy' (1998) 21 Journal of Consumer Policy, 131; S. GRundmanN, W. KeRber, and S. WeatherILL, 'Party Autonomy and the Role of Information in the Internal Market - an Overview', in S. GRUNDMANN, W. KERBER, and S. WeAtheriLl (Eds.), Party Autonomy and the Role of Information in the Internal Market, (Walter de Gruyter, BerlinNew York: Walter de Gruyter, 2001) 7; S. GRUNDMANN, 'Verbraucherrecht, Unternehmensrecht, Privatrecht warum sind sich UN-Kaufrecht und EU-Kaufrechts-Richtllinie so ähnlich?', (2002) 202 AcP , 40, 61.
} 
Directive 2005/29. I will also concentrate on the major policy options and substantive rules in the Directive and I will disregard, for the purposes of this paper, the issues of enforcement and procedure (essentially art. 11), Codes of conduct (art. 10) and the boilerplate provision of effective, proportionate and dissuasive penalties (art. 13).

The article is organized as follows: Section II examines the possible rationales that can theoretically justify a set of rules such as the ones present in Directive 2005/29; section III addresses the scope of the Directive and criticizes some of the major solutions in Directive 2005/29; section IV looks at the mechanism for defining unfairness in commercial practices; section $\mathrm{V}$ briefly concludes.

\section{The plausible goals and organizing principles in regulating commercial practices}

I do not purport to question let alone to challenge the candidness of the European legislators -a complex and varied bunch in itself, to be sure- about their true intentions behind the adoption of Directive 2005/29, but to place the inquiry into the intended and unintended consequences of the new rules into some normative framework. For this, I think it is useful, at least arguendo, to briefly review the rationales that a general regulation on business behavior towards consumers may cogently pursue ${ }^{5}$.

\subsection{Efficiency in $b 2 c$ transactions}

From an economics perspective, it seems logical to start with efficiency as a plausible mission in the regulation of commercial practices in the business-to-consumer relationship. In a business-toconsumer interaction (in fact, in any voluntary interaction as seen from an economic perspective), the desirable outcome is that the surplus from the voluntary interaction becomes as large as technologically or otherwise materially feasible, that the surplus is maximized, to use the mathematical jargon economists tend to favour. Competition in the markets for goods and services seems to be the first place to look at to achieve this desired efficient outcome. As simple economic theory shows, perfect competition ensures that all consumers who value a certain good or service at more than what it would cost for the society to produce the good or provide the service, will obtain it at the price which reflects the exact social cost. Allocative and productive efficiency are simultaneously achieved. Competition forces firms to offer the most attractive combination of prices and qualities technologically available, and consumers are thus able to find the price/quality (very broadly and abstractly, hence somewhat unrealistically, defined as any

\footnotetext{
${ }^{5}$ I am referring here to goals beyond the general goal or goals of all legal rules, which many, at least those who believe in the coherence and purpose of a legal system, think do in fact exist, be they justice, equality, happiness, efficiency, wealth maximization, social welfare, or other imaginable goal. I do, in fact, think that the whole theoretical and human machinery of the legal system is not a blind enterprise, and that there is a fundamental common purpose in it - albeit instrumental and not self-defined -, but what I am referring to here is a narrower sense of goals than the fundamental ends of the legal system: More specific and operational objectives of the regulation of firm behavior with respect to consumers.
} 
product feature outside price) that best suits their preferences, a happy combination that maximizes the sum of producers and consumers' welfare $^{6}$.

But not even the most devout believers in the benefits of competitive markets think this nirvana happens by mere chance, nor needs the helping hand of Government and the legal system. Although consumers are able sometimes, maybe even often, absent any legal or regulatory standards and remedies, to discipline untrustworthy or otherwise undesirable firms through the simple mechanism of not buying again and taking business elsewhere, this is not always the case. Reputation and repeat sales may not deter fly-by-night or scam operators, and general rules and remedies in Contract law sanctioning duress, fraud, and breach of contract, and even rules in Criminal law may be often necessary. Still, the latter cannot adequately respond to instances of contract breach that are not verifiable in a Court of Law, or to behaviour of firms that are entirely, or almost, judgement-proof, and thus, undeterrable using ex-post monetary sanctions, or to cases of small-scale -but numerous- individual harm to consumers, against which it is rational for them to forego legal remedies in private law, due to the high fixed costs of individual suits. In these circumstances, there is a role, acknowledged even by those generally very critical of Government intervention, for regulatory duties and public enforcement mechanisms. ${ }^{7}$

Consequently, at least in theory, from a pure efficiency perspective, there is space for the imposition of regulatory requirements on firm behaviour towards consumers, affecting communication, advertising, sales promotion, contracting and pre-contracting conduct, and so on, in order to increase the surplus in the firm-consumer relationship. The core issue, under such a goal, is how to design and apply an optimal system of duties of information and behaviour that covers the gaps that market forces are unable to check, and, at the same time, does not interfere with those same driving pressures of competitive markets which, overall, are the major factors in attaining optimality in the relationship between producers and consumers ${ }^{8}$. Of course, the various dimensions concerning the scope of the regulatory measures are crucial issues to consider. Is the European level the optimal level to attempt such a corrective intervention in consumer markets, or should it be better left to the Member States, which are, all in all, more homogeneous in terms of preferences, probably also those affecting these matters? Should the regulatory measures be adopted as a general and relatively uniform "Code" of mandated firm

\footnotetext{
${ }^{6}$ Moreover, the surplus generated by the production and provision of goods through the competitive market accrues entirely to consumers, so their position cannot be improved by Government policy or legal rules. This is, however, a distributive matter between firms and consumers, and outside the realm of pure efficiency.

7 P. RuBin, 'The Economics of Regulating Deception' (1991) 10 Cato Journal 667, 675; P. RuBIN, 'Regulation of Information and Advertising' (2004) Emory School of Law, Law and Economics Research Paper Series, WP No. 04-05, 6 at http://ssrn.com/abstract=498683; T. MURIS, 'The Federal Trade Commission and the Future Development of U. S. Consumer Protection Policy' (2004) George Mason University School of Law, Law and Economics Working Paper Series, 04-19, 7-16 at http://ssrn.com/abstract_id=545182

8 Although there is no a priori theoretical reason for the assertion, I think implausible that legal intervention by itself can be a global substitute to robust competition to achieve a high level of consumer welfare. It seems that the idea of an effective European internal market is, partially at least, based upon this conviction. Consequently, any efficient regulation of firm behaviour towards consumers should not undermine the force of competition favouring consumers.
} 
behaviour across product markets and contexts -a broad catalogue of permitted and prohibited practices, such as in Directive 2005/29-, or should a more fragmented approach that takes into account the specifics of each market or group of markets -an strategy based upon sectorial Directives- or of each kind of practice -advertising, sales promotion, contracting- be more advisable?

\subsection{The redistributive ideal}

A second plausible -at least at first blush, and for many lawyers and policy-makers, in any caseobjective of regulating the practices of firms affecting consumers would be to benefit the latter at the expense of the former, that is, to redistribute welfare, or income more narrowly, from producers to consumers. It is entirely sensible to think that the gains from trade and interaction between producers and consumers are unequally distributed among both groups, and that the legal system should attempt to correct the imbalance in this distribution. The unavoidable premise of such a normative conclusion is that the real-world market structures actually are far from the perfectly competitive ideal ${ }^{9}$, and that imperfect competition reigns, arising from the presence of a single producer or a group of producers acting like a single producer, that is, monopoly and collusive behavior: When a monopolist, or a group of firms behaving like one, restricts output to maximize profit, it causes a raise in price above the competitive level. This will bring about a shift in the ultimate beneficiary of the surplus of the market exchange. A fraction of this surplus (even the whole surplus, under certain conditions) will be transferred from consumers to producers, making the former worse-off and the latter better-off ${ }^{10}$.

In less than perfectly competitive market structures, it is therefore theoretically feasible to improve the lot of consumers at the expense of firms. The level of duties of firms vis-à-vis consumers, and/or the level of rights of consumers, can be raised to the effect of increasing the welfare of consumers. The problem is that firms and consumers are, or are likely to be, in a contractual or otherwise voluntary situation, which allows the parties to alter the terms of trade or the exchange. An increase in duties or rights that is not efficient, in the sense of increasing the surplus of the interaction, will imply a readjustment of the terms to the detriment of consumers

\footnotetext{
9 Under perfect competition, all surplus from trade accrues to consumers, so additional redistribution in their favour is an oxymoron. It is true that real-world markets differ from the perfectly competitive paradigm, due to its very exacting requirements. The standard assumptions in economic theory for a perfectly competitive market are the following: atomicity of producers (the number of producers is so large that no single producer has an impact on what others do); product homogeneity (the products by all different producers are perfect substitutes); perfect information (both producers and consumers have perfect knowledge of all relevant variables); equality of producers (all producers have the same technology and cost functions); free and unlimited entry (any producer may enter or exit the market as it wishes). Of course, this set of assumptions clearly shows that perfect competition is a theoretical construct, and that it is not something that we can derive by induction or observation from real-world markets. Still, it is an extremely useful benchmark to evaluate the performance and the possible corrective measures in real life markets.

10 More importantly in economic terms, the restriction in output will determine that some consumers who value the good or service above the social cost of its provision - but less than the monopoly price- will be deprived of the possibility of its purchase, and will be forced either to do without it, or else to turn to less-preferred -or more costly to produce in social terms- alternative goods.
} 
that cannot be compensated by the increased consumer welfare due to a higher level of firms' duties or consumers' rights ${ }^{11}$. Thus, a purely redistributive legal intervention -one that does not increase joint welfare apart from how this welfare is shared among the parties to the interactionis very likely to become moot due to the readjustment in price and/or other terms of the transaction, when the affected parties find themselves in a contractual or semi-contractual situation. Such a redistributive goal would thus be largely self-defeating, and does not provide an appealing foundation for a set of rules as the ones contained in Directive 2005/29.

\subsection{The market manipulation theory}

A slightly different goal, however, and one that would escape the objection just raised against a purely redistributive intervention in consumers' markets, would be to prevent undue influence, or outright manipulation, by firms -essentially through advertising, sales promotions, and other marketing techniques- of consumers' preferences. In recent years, psychologists and behavioural economists have identified, described and experimentally analyzed several cognitive and behavioural biases in human beings, all of which imply a significant departure from the standard model of human behaviour -and also consumer behaviour- typically assumed by economic analysis ${ }^{12}$. People have been shown to be bad statisticians and users of factual information, to be over-confident, to poorly assess risks of all kinds, and to have time-inconsistent, status-quo based, and other-regarding preferences. Some commentators ${ }^{13}$ argue that many, if not most commercial practices are but instruments in the hands of firms to manipulate those biases in their benefit: Advertising, promotion, and price setting are ways to alter consumer preferences to the advantage of firms.

The goal of opposing the manipulation of consumers' tastes and choices by the producers, although containing some redistributive flavour, is conceptually different. Distributive motives take preferences by consumers as granted, and simply try to enlarge consumers' size of the social welfare pie. Here the crucial issue is the formation of consumers' preferences and how firms

11 The brief statement given in the text summarizes the outcome when consumers are homogeneous. When consumers differ in terms of the valuation of the increased duties or rights, the analysis is more complicated, and the result more ambiguous, because there may be winners and losers among the group of consumers, thus raising distributive issues inside them. The qualitative implication, namely that inefficient legal intervention reduces overall consumers' welfare, still holds in this more complex scenario. See R. CRASWELL, 'Passsing-On the Costs of Legal Rules: Efficiency and Distribution in Buyer-Seller Relationships' (1991) 43 Stanford Law Review 361, 372-380. In the same sense, see D. WEISBACH, 'Taxes and Torts in the Redistribution of Income', (2002) University of Chicago Law School, John M. Olin Program in Law \& Economics, Working Paper No. 148. Not everyone agrees on this, of course: I. RAMSAY, 'Consumer protection', in P. NewMAn (editor), The New Palgrave Dictionary of Economics and the Law, vol. I (London: MacMillan, 1998) 413.

\footnotetext{
12 Probably the best introduction to this literature for the use of the Law is C. JOLLS, C. SUNSTEIN, and R. THALER, Behavioral Law and Economics (Cambridge: Cambridge University Press, 2002). In the consumer context, J. D. HANSON, and D. A. KYSAR, 'Taking Behavioralism Seriously: The Problem of Market Manipulation' (1999a) 74 New York University Law Review 630; J. D. HANSON, and D. A. KYSAR, 'Taking Behavioralism Seriously: Some Evidence of Market Manipulation' (1999b) 112 Harvard Law Review 1420.
}

13 See J. D. HANSON and D. A. KYSAR (1999a), 641. 
consciously interfere with a fair process of choice by consumers. In some sense, there is a fairness flavour to it, pointing at the policy of using the Law to impose ethical constraints on the commercial practices of firms towards consumers ${ }^{14}$.

It is highly likely that such a fairness motivation against preference manipulation lies behind several rules in consumer protection Law generally, as well as in European consumer Law. In fact, it looks apparent to me that many of the practices contemplated as aggressive in art. 9, and items 24 and following in Annex 1 of Directive 2005/29, seem to be clear and obvious examples of the kind of preference manipulation that lies at the core of consumer protection under this goal. There are some problems with this approach, however, that make it an unlikely candidate to serve as the main normative principle behind the regulation of commercial practices, such as the one contained in Directive 2005/29. First, if we take the market manipulation argument at face value, then the regulation of commercial practices should restrict almost any of them, given that they all try to convince or persuade consumers to buy the products or services of a specific producer.

Commercial practices are primarily (and intended to be) means of persuasion, not means of informing the consuming public (though consumers may be able to extract information from those practices). The end result is that no communication with consumers will ever take place, given that with it firms are trying to alter the choices by consumers. Let's think only of some of the examples that the most outspoken proponents of the market manipulation thesis present: Cookie shops venting the smell of cookies into the shopping mall -and not outside- to trigger the visceral factor of hunger; ads of spirits showing bottle, glass and ice, to make consumers visualize, and hence, live the experience of drinking; money-back guarantees, test trials of the product, free samples, as marketing ploys to create in the consumer a sense of ownership of the product, and thus exploit the status quo bias and the endowment effect ${ }^{15}$. If the Law of commercial practices did in fact try to eliminate such well-internalized and widely-used marketing tactics as the ones just cited, or other to similar effect, the enforcement costs of the regulation would sky-rocket, because almost any marketing technique would be prohibited, and the incentives to violate the prohibition, even at a small-scale level, would be very high, determining prohibitive costs of enforcing the regulation to any politically acceptable level. Moreover, the result of a marketplace with no advertising and no marketing strategies seems, at least to me, bleaker than a marketplace with some preference manipulation and distortion.

\footnotetext{
14 For instance, R. SCHECHTER, 'The Death of the Gullible Consumer: Towards a More Sensible Definition of Deception at the FTC' (1989) University of Illinois Law Review 571, 607-608. Many Law and Economics scholars, however, are very critical of fairness goals of legal rules, advocating a narrow welfarist conception of legitimate (useful, would be perhaps more appropriate) goals of the legal system: See L. KAPLOW, and S. SHAVELL, Fairness versus Welfare (Cambridge (MA)-London: Harvard University Press, Cambridge, 2003).
}

15 See J. D. HANSON and D. A. KYSAR (1999a), 733 and following. 
The second reason lies in the fact that the market manipulation story goes too far. Cognitive and behavioural biases by consumers ${ }^{16}$ are very real, for sure, but they do not make consumers mere puppets in the hands of firms. In an important paper, DeLla VIGNA and MALMENDIER ${ }^{17}$ have shown that if consumers are aware of their biases and weaknesses as consumers (although they are unable to correct them by themselves), then firms will be interested in supplying through contractual means and clauses the commitment devices to overcome the lack of self-control by consumers, thus restoring efficient outcomes. So if consumers are sophisticated, and knowledgeable of their own shortcomings in terms of self-control, firms not only are unable to exploit consumers' weaknesses, but in fact can help them so they are not harmed, in terms of welfare, by the lack of self-control.

There is also substantial empirical evidence ${ }^{18}$ that consumers are not blindly fooled and persuaded by all communicative actions by firms, most notably by advertising. Consumers tend to think that communication by firms is relatively untrustworthy, although they are able to obtain valuable information from it concerning the relevant features of the product or service, or the projected transaction ${ }^{19}$. In sum, many empirical studies show that consumers, knowing their own lack of self-control, or of information, extract some information from what firms say, but remain overall skeptical of the statements and communications coming from producers.

All this implies that cognitive and behavioural biases per se do not impede that market forces can perform relatively well also if consumers are relatively impulsive, weak, or uninformed. If they are aware of where their biases lie, the chances of market manipulation diminish, and thus the need to introduce legal means to correct market outcomes. This does not imply that firms do not attempt, and succeed sometimes, in taking advantage of the cognitive and behavioural biases affecting consumers, and that legal rules cannot improve upon this undesirable situation. A good example, at least in the US context, is the credit card market, in which consumers gravely underestimate their future borrowing against their credit cards, and issuers exploit this bias by using teaser entry rates, and exploitative interest rates and late-payment fees. Legal measures

\footnotetext{
16 In fact, the biases seem to be universal among humans, so they also afflict the human beings that manage and run the firms who engage in consumer manipulation. It is true, however, that repeat play is likely to reduce the impact of the biases, and repetition seems more probable with individuals within firms than when acting as consumers.
}

17 S. Della Vigna, and U. Malmendier, 'Contract Design and Self-Control: Theory and Evidence' (2004) 119 Quarterly Journal of Economics 353. In their paper, they use the case of an hyperbolic discount function by consumers (they irrationally value the present too much, and disregard the future) and two different goods: an "investment " good, with instant costs and future benefits -health club attendance is their example- and a "leisure" good, with immediate benefits and delayed costs -they use the example of credit card borrowing- . Only true naïve consumers can be exploited by firms, those who know their own irrationally -albeit unable to change it- are in fact helped by firms. In economic terms at least, the classical advice of Nosce te ipsum seems to pay.

18 This evidence is aptly condensed in J. E. CALFEE, Fear of Persuasion. A New Perspective on Advertising and Regulation (Monnaz: Agora-AEI 1997) 37 and following.

${ }^{19}$ In fact, if consumers believed nothing, and obtained no information from advertising, we would not observe it in the real world, a prediction clearly falsified by reality. 
increasing disclosure of rates, and thus awareness of the dangers of borrowing by consumers ${ }^{20}$, toppled, perhaps with forced decoupling of payment and credit services, and even mandatory ceilings in interest rates, may (but only may) contribute to ameliorate the lot of consumers in this market ${ }^{21}$.

A third problem in adopting market manipulation avoidance as the overarching goal of regulating commercial practices lies in the fact the kind of legal intervention that, in all likelihood, would be required to achieve this goal, would entail most of the costs and negative effects of paternalistic policies generally, from the general philosophical (or moral, if one prefers) argument against paternalism, to the unwanted side-effect of eliminating much valuable free choice, to the real dangers of regulatory capture by interest groups, not necessarily those more representative of the needs of consumers ${ }^{22}$.

All in all, then, the market manipulation agenda, or imposing values of fairness in b2c transactions, does not seem to be able to provide an appealing overall objective for general regulatory measures of firm behaviour towards consumers such as Directive 2005/29.

\subsection{Removing barriers to trade with consumers across borders}

As previously noted, the objective of removing barriers that hamper the smooth functioning of the internal market in goods and services, looms large in the Directive. The internal market, or the harmonization goal can be understood as comprising two different elements or perspectives. One refers to the reduction for firms of the costs of doing business in various national markets: If a firm plans to carry out an advertising campaign covering several, not to say all Member States, the costs of compliance are much higher in the presence of different legal and regulatory requirements than with a single set of legal conditions for the campaign. It is in fact this

\footnotetext{
20 In Europe, the problem has also been perceived and, better or worse, tackled. The standardized and mandatory annual percentage rate that Directive 87/102/EEC of 22 December 1986 on consumer credit (modified by Directives 90/88 and 98/7) defines and imposes upon all consumer credit contracts, including credit card contracts, would be a paramount example of a legal measure increasing levels of disclosure to raise awareness of the present-term costs of future borrowing. Not that standardized disclosure requirements do not pose some economic costs of their own: they can induce producers to concentrate quality efforts on the variables included in the standard, at the expense of others left out of it, that may be also important to consumers, and the required disclosure may displace other information that the producer would have conveyed, and might also have been informative to consumers. See, H. BEALES, R. CRASWELl, and S. SAlOP, 'The Efficient Regulation of Consumer Information' (1981) 24 Journal of Law and Economics 491, 523 and following. Regarding the specific standardized disclosure requirement in consumer credit contracts, some have criticized this from an economic perspective, stressing the increase in compliance and litigation costs, the negative effects on credit collection terms and customer service (variables not included in the standard disclosure), and the fact that only already well-informed and wealthy borrowers are likely to benefit from it. See R. POSNER, Economic Analysis of Law, $5^{\text {th }}$ edition (New York: Aspen Publishers, 1998) 408; R. HyNES, and E. POSNER, 'The Law and Economics of Consumer Finance' (2002) 4 American Law and Economics Review 194-195.
}

21 A cogent defence of this view, in O. BAR-GILL, 'Seduction by Plastic' (2004) American Law \& Economics Annual Meeting Papers, available at http:/ /law.bepress.com/alca/14th/art12.

22 See J. RACHLINSKI, 'The Uncertain Psychological Case for Paternalism' (2003) 97 Northwestern University Law Review 1165. 
dimension of harmonization the one underlined by many commentators of Directive 2005/29, the Draft Directive, or European consumer Law more generally. ${ }^{23}$

Others ${ }^{24}$, in turn, downplay the importance and reach of the cost-reducing effect of the Directive, mainly due to the fact that regulatory diversity will not disappear as a consequence of a harmonizing Directive, because even if the Law in the books is the same in the different Member States, the Law in action will definitely differ widely, due to diverse enforcement strategies and views. Moreover, the need to adapt to local market conditions will always impose costs on crossborder marketing activities by firms, and thus the extra cost of more complex regulatory compliance in various jurisdictions would be close to negligible. Some argue, to a similar effect, that the perspective of reducing costs for firms is not the adequate one to make ground for crossborder trade. Consumer perceptions about legal and other uncertainties and shortcomings of transacting over the national borders would be the key building blocks of the barriers to crossborder trade, and thus the crucial factor affecting the implementation of the internal market through regulatory and legal harmonization ${ }^{25}$.

Both dimensions deserve some remarks from a Law and Economics perspective. It is hard to deny that regulatory complexity and variety entails some level of transaction costs for firms contemplating commercial activities in the different areas covered by the diverse legal and regulatory regimes. Lawyers are specialized professionals who obtain quasi-rents from, among others, the task of assessing, managing and minimizing the risks associated with such diversity. The phenomenon is observable even within national borders, in federal systems in which the individual regional entities have substantial powers to design and impose their own regulations. Whether this diversity is a relevant obstacle to the formation and flourishing of a vigorous unified market is a different -and entirely contingent and empirical- matter. Consequently, a reduction in complexity and disparity would, most plausibly, produce some gains. These gains are both static and dynamic in nature. Since $\operatorname{COASE}^{26}$ we know that transaction costs are real costs of taking economic actions, and that they are not subordinate in importance to technological or other costs. So a decrease, however slight, in the transaction costs involved in cross-border commercial activity actually entails a reduction of real costs in the economy, a direct and tangible social benefit. Who will benefit more in the end of this cost reduction depends upon market structure and the elasticity of demand for the different goods and services experiencing the diminution in transaction costs. But there is also a dynamic gain resulting from this reduction of transaction costs of cross-border commercial relations between firms and consumers. Transaction costs created by regulatory heterogeneity erect barriers to entry in national markets for foreign

\footnotetext{
${ }^{23}$ L. GonZÁLeZ-VAQUÉ, 'La Directiva 2005/29/CE relativa a las prácticas comerciales desleales en materia de protección de consumidores' (2005) 18 Derecho de los negocios 5, 6; BusCH, note 3 above, 91-92; S. GRUNDMANN, 'European Contract Law of What Colour?' (2005) 2 European Review of Contract Law 184; K. RIESENHUBER, 'System and Principles of EC Contract Law' (2005) 3 European Review of Contract Law 296, 303.

24 See COLLINS, note 2 above, 17.

${ }^{25}$ See COLLINS, note 2 above, 16; J. STUYCK, E. TERrYN, and T. VAN DYCK, note 2 above, 243.

${ }^{26}$ R. H. COASE, The Firm, the Market and the Law (Chicago: University of Chicago Press, 1991).
} 
firms, so a decrease in the former imply an enhanced chance of entry, and thus, enhanced competition in each of the affected national markets. As is well-known from standard economic theory, most gains from increased competition finally accrue to consumers.

The perspective of consumers is of course important, and not just for the reason that many of the static and dynamic gains of reducing costs for firms in engaging in cross-border transactions and activities ultimately result in the benefit of the consuming public. Consumers also face transaction costs in cross-border trade, and these are also real economic costs, whose reduction would also bring both static and dynamic gains. The additional problem here is that the perceptions of consumers on the real importance of diversity, and the extent of the reduction brought about by the harmonized rules are, with high likelihood, less accurate than those of firms. Hence, even if a real reduction in regulatory diversity and legal uncertainty in cross-border transactions has taken place, if consumers are slow, or myopic, in evaluating the new situation, purely perceived or imaginary -but effective nonetheless, here- transaction costs would remain at the previous high level, and very little, if any would have been gained.

The biggest issue, however, is that all the former considerations refer only to the benefit side of the necessary balance in order to evaluate harmonized rules as a desirable instrument to implement the internal market. Harmonization also has its costs. I am not well-placed to revisit the general arguments already discussed in the literature on the relative advantages and disadvantages of competition vs. harmonization as legal strategies in a world of diverse nations and jurisdictions. But it is apparent that, in the current European context, it is far from clear that a uniform ${ }^{27}$ pan-European regulatory content would be optimal for the conditions of all national consumer markets, and the various societal preferences concerning authorised and un-authorised commercial practices ${ }^{28}$. It is true that Directive 2005/29, even if it had been finally adopted which in fact was not- as a total harmonisation Directive, would not really mean that firms would be subject to exactly the same regulatory requirements in their commercial activities towards consumers everywhere in Europe. As will become apparent in later sections, the rules present in the Directive are based on the use of standards (professional diligence, average consumer) and notions (misleading action and misleading omission, invitation to purchase) which allow ample room for interpretation and judgement in accordance with the specific circumstances of the national and/or product market affected, and thus, permit a relatively wide variety of

27 The level of uniformity in the regulation has diminished in the final version with respect to the proposal of 2003. In the latter, the proposed rules implied -although there was no explicit total harmonisation clause, only the preamble referred to it- maximum or total harmonisation (no possibility of more strict rules by Member States) and included a very explicit country of origin rule in art. 4.1. The final text, however, has eliminated the strongworded country of origin formula, and explicitly allows for more stringent national rules, along two dimensions: without limitation, in the field of financial services and immovable property (art. 3.9); for a temporary period of 6 years starting at the time of the expiration of the transposition deadline, when essential for adequate consumer protection and implementing other Directives with minimum harmonisation clauses (art. 3.5). It is clear, though, that even the final text is far from a traditional (in the field of consumer protection) minimum regulation Directive. On these issues, see J. STUYCK, E. TERRYN, and T. VAN DYCK, note 2 above, 263-269; H.-W. MiCKLITZ, 'A General Framework Directive on Fair Trading', in H. Collins (editor) The Forthcoming EC Directive on Unfair Commercial Practices (The Hague/London/New York: Kluwer Law International, 2003) 43, 75-76.

28 Similarly, see G. HowELLs, 'The Scope of European Consumer Law' (2005) 3 European Review of Contract Law 360,367 . 
substantive outcomes. The enforcement of the provisions of Directive 2005/29, though with some harmonised principles, is largely left to Member States, another very significant source of variety in the real solutions implemented in the different national markets.

Despite these undeniable loopholes in the harmonisation effort, it is almost axiomatic (or else Directive 2005/29 would be entirely a wasted endeavour) that uniformity of effective regulatory outcomes on commercial practices would increase, probably substantially, as a result of the new Directive. And this uniformity would imply a reduction -neutrally understood, not necessarily good or bad from the standpoint of efficiency, for instance- in the current levels of regulatory stringency in some countries: less information duties, less obligations to justify statements in commercial communications, and so forth. It would also imply an increase in such levels for other countries. If (a big if, however) the existing levels were optimal given the conditions of markets and consumers, and the preferences of voters in each country, such a move towards uniformity would entail costs and losses to the affected parties and to the disinterested and representative voter. Whether these costs outweigh or not the benefits of more unencumbered cross-border trade, is something very difficult to establish, even to guess, at a general level. It is perhaps possible to empirically assess those costs and benefits, probably on a less ambitious level (for some products and services) but I am not aware of any available and respectable published results along those lines. Thus, the general question concerning the cost-effectiveness of the harmonisation effort in the field of commercial practices remains, theoretically, unresolved, though some informed guesses can be made with respect to more specific issues in Directive 2005/29.

\section{The efficiency of the scope of Directive 2005/29}

In terms of scope and intended reach, Directive 2005/29 is notoriously ambitious in its pretension to cover all commercial practices and all markets for goods and services. One could say it has been conceived as a rule of universal reach for commercial activity.

From an economic perspective, three of the drafters' choices concerning the scope of the Directive seem particularly noteworthy. The first refers to the decision (art. 3.1) to restrict its reach to business-to-consumer commercial practices, without affecting '...the national laws on unfair commercial practices which harm only competitors' economic interests or which relate to a transaction between traders;' (recital (6) of the Preamble). There has been substantial debate ${ }^{29}$ concerning the appropriateness of this restriction, which departs from the tradition of most Member States to include in the legal regime of commercial practices also those affecting competitors or other professional participants in the market. From an economic perspective, it is not immediately clear whether the general regulation of unfair commercial practices should include both those addressed to consumers and those addressed to other firms. Probably for political and constitutional reasons it was more practical, in order to move forward with the Directive, to limit the scope to activities immediately affecting consumers. In economic terms, given the most

\footnotetext{
${ }^{29}$ See note 2 above for some references.
} 
relevant kind of practices and prohibitions contemplated in Directive 2005/29 -disclosure rules to avoid misleading omissions in communication and invitations to buy, active misleading or aggressive practices- there are enough important differences between the median consumer and the median professional market operators in those respects, as to make the diversified regime consumers/professionals a sensible choice, or at least not an obviously mistaken one. It is likely that the typical practices that will be covered by the prohibitions in arts. 5 to 9 of Directive 2005/29 will present substantially dissimilar profiles when addressed to consumers as when directed to other traders operating in the same market.

The second major choice in terms of regulatory coverage concerns the range of economic actions or activities affected by the rules in Directive 2005/29. The definition contained in art. 2 (d) on 'business-to-consumer commercial practices' is broad and almost all-encompassing: 'any act, omission, course of conduct or representation, commercial communication including advertising and marketing, by a trader, directly connected with the promotion, sale or supply of a product to consumers;'. This definition is but one important illustration of the purpose of Directive 2005/29 of building a general and relatively uniform set of rules covering, in principle, all markets and circumstances in which a commercial activity takes place. Such a 'generalist' approach to regulating commercial practices, even if circumscribed to b2c, is likely to be overstretched. The reason is that markets and circumstances do matter much for the economic consequences, and the optimal way to regulate, in case it were required, of different commercial actions in which firms engage to contact and interact with consumers. The same consumer acts very differently according to the market he or she is in: One does not buy a house investing all life's savings with the same degree of information, and under comparable influence from advertising, as when buying a pair of shoes, a bottle of soda, or a pharmaceutical product. Also, the existence and role of informational intermediaries (advisors, independent information providers, mandatory decision-makers, such as doctors in prescribing) varies enormously from one market to another. Another crucial differential factor is the impact on consumer's welfare of the relevant commercial practice. In some circumstances, the effect of an undue change in the behaviour of the consumer as a result of a given practice by firms may be life-endangering, or otherwise devastating, while in other instances the effect is trivial, and can be easily corrected or absorbed, much outweighing the trouble and cost of imposing and enforcing a regulatory measure. In other words, the balance of costs and benefits is heavily market- and context dependent, a fact that, in principle, would call for diversified regulatory responses ${ }^{30}$.

It seems that the drafters and promoters of Directive 2005/29 are confident, perhaps too confident, in the use of general clauses, or other instruments in the legal tool-kit also capable of being adapted to the case-specific circumstances by the interpreter or enforcer of the legal rule. It is undeniably good to have general and abstract theories and analytical tools, capable of

\footnotetext{
30 This assumes that the balance of costs and benefits, in short, cost-benefit analysis is the adequate normative benchmark for designing regulatory policy, including legal policy. There seems to be agreement among economists and economically inclined lawyers that this is the case, though disagreement exists about how to best conduct and use cost-benefit analysis for improving legislation and regulation. The literature on this topic is too broad even to be sketched, but excellent references are the Symposium issue 'Cost-benefit Analysis: Legal, Economic, and Philosophical Perspectives' (2000) 29 Journal of Legal Studies; L. HeInZERLING, 'Regulatory Costs of Mythic Proportions' (1998) 106 Yale Law Journal 1981.
} 
illuminating and helping to understand a wide variety of social phenomena. But legal rules are not instruments of knowledge, but direct and indirect motivators of human conduct, and here the reliance on abstract and uniform formulas for heterogeneous situations may be, sometimes, excessive.

Nevertheless, provided that coverage under the Directive is desired to be market- and circumstance-unespecific, the notion of commercial practice introduced in art. 2 (d) seems adequate in its breadth. It would be pointless to try to subject all markets, and potentially all contexts in which b2c commercial activity takes place, and then use a somehow restrictive notion of the subject matter in terms of the actions covered. Firms contact and address consumers to persuade them to buy. This is the essence not just of narrow marketing behaviour (advertising, promotional activities, product placement and the like) but of all kinds of contact, direct or indirect, of firms with prospective customers. It makes sense also not to leave post-contract behaviour outside the picture, because it can be anticipated by consumers and thus influence their consumption decisions.

Along similar lines, again assuming, for argument's sake, the merit in a policy of general coverage, the use of the notion of transactional decision as the other side of the coin in the business-to-consumer relationship, and the content of the notion, both seem coherent. Transactional decision is 'any decision taken by a consumer concerning whether, how, and on what terms to purchase, make payment in whole or in part for, retain or dispose of a product or to exercise a contractual right in relation to the product, whether the consumer decides to act or to refrain from acting;'. The definition intends to cover the entire range of consumer's behaviour either before, during or after purchasing, which seems adequate given that the whole range can be affected by a commercial practice and have an effect on overall consumer's welfare.

A reference to contract would be appropriate here. Art. 3 (2) leaves contract law untouched, and in particular the rules on validity, formation and effect of a contract. If the intention is simply to state the obvious fact that the Directive should not be understood as substituting existing private law rules on contract, fair enough. It should be made clear, however, that communication between the provisions of Directive 2005/29 and rules of contract law, specially European contract law would be active: Several regulatory choices in the Directive are influenced by contract law and, in turn, would influence the interpretation and application of contract law rules. For instance, art. 2.2 (d) of Directive 1999/44/EC on certain aspects of the sale of consumer goods and associated guarantees contains a rule of conformity of goods to the contract, for the assessment of which it mandates to take into account any public statements made by the seller or the producer, particularly in advertising and labelling. Thus, the requirements of information mandated by Directive 2005/29 for advertising and other promotional practices would have a clear impact in the interpretation of the contract through the said article of Directive 1999/44. On the other side, art. 7.5 of Directive 2005/29 includes the content of many informational requirements imposed by sectorial Directives, many of which are contract law, at lest in substance, if not formally, in the material disclosure forced upon commercial communications in order to avoid being considered a misleading omission. 
A third important choice in terms of scope refers to the relevance or impact of the practice to be deemed unfair. The crucial notion here is that of materially distorting the economic behaviour of consumers. Directive 2005/29 is concerned thus with commercial practices that do matter for the actual response and behaviour of consumers. The notion is defined in art. 2 (e): 'using a commercial practice to appreciably impair the consumer's ability to make an informed decision, thereby causing the consumer to take a transactional decision that he would not have taken otherwise;'. The test based on this notion is explicitly deployed in art. 5.2 (the general clause against unfair practices), and implicitly used in arts 6.1,7.1, 7.2, and 8. The starting point behind this idea is sensible: It makes sense to restrict and deter commercial practices vis-à-vis consumers only when they are harmful to them. If there is no harm, or only negligible harm, to engage the costly machinery of legal intervention is just a waste of scarce resources.

The notion of material distortion of the economic behaviour of consumers thus seems to serve as a proxy for the harmfulness of the practice. As a proxy for harm, however, some problems may appear with this notion. First, its core normative content is based upon an exercise in counterfactuals: the distortion exists if the observed decision taken by the consumer exposed to the commercial practice departs from what would otherwise have been his or her decision. And counterfactuals $^{31}$ are always complicated to execute properly, specially if no clear benchmark is provided for the exercise, as happens with this key notion in Directive 2005/29: Does otherwise refer to the same consumer with perfect information, or to a consumer with access to a -barelylawful commercial practice, or by the median commercial practice, or to one entirely unaffected by any commercial practice whatsoever? ${ }^{32}$ No clear clue appears in that notion, and not even with the help of other notions (such as the average consumer, appearing in art. 5.2) there is a discernible answer, let alone a straightforward one. Second, as a proxy for harm to consumers, the notion of material distortion of the economic behaviour of consumers as it appears in Directive 2005/29, is too focused on the starting point of the commercial practice. As it stands, the commercial practice has to impair -may be unless it qualifies as a misleading omission- the consumer's ability to make informed choices, so the shift from the baseline -whatever it may berequires some kind of behaviour attributable to the firm engaging in the commercial activity. This implies that pre-existing errors, misinformations or misrepresentations on the part of consumers, unless they can be linked to a previous statement or precise omission of the trader in question, cannot serve to build a result of unfairness in the underlying commercial practice. From a purely economic perspective, this linkage should not be a pre-requisite for imposing duties upon firms engaging in commercial communications or commercial practices generally. If these firms, although not responsible for the level of information prevalent among consumers, are wellplaced (may be trough their market-leader position, or through technical advantages, or through economies of scale in advertising) to increase the information useful for consumers so they can make more informed choices, there is no economic reason not to require them to do so. That is, if firms can, in a cost-effective way, correct inadequate levels of information on the part of

31 It is, however, undeniable that almost all forms of assessing harm ex-post (or ex-ante, if we think of general regulatory standards) imply some degree of counterfactualism.

32 For an analysis of such issues in the context of deceptive advertising, see R. CRASWELL, '"Compared to What?" The Use of Control Ads in Deceptive Advertising Litigation' (1997) 65 Antitrust Law Journal 757. 
consumers, their practices should be deemed unfair if they do not engage in these educational or corrective actions. In cost-benefit terms, they are the cheapest providers of a social benefit.

\section{Setting the test for unfairness}

As has been widely acknowledged by all commentators of the Directive and the Proposal, the finding of unfairness of a given commercial practice is organized in a complex way in Directive $2005 / 29$. There are several different levels of analysis, giving rise to a three-step procedure to establish unfairness. The more general level is a general clause of unfairness, set out in art. 5, and expressed in a double requirement: Violation of professional diligence, and material distortion of the economic behaviour of the average consumer. The second level is made operational through the concepts of misleading and aggressive practices, which, in turn, are subject to a more precise enumeration of factors giving rise to a finding of misleading -both in action and in omission- and aggressive practice. Last, a black list of specific commercial practices, presumably -although some of them, implausibly- having been found in real-world commercial experience, which are, in all circumstances, considered unfair, regardless of the verification of the presence or absence of the elements or factors on which either the general unfairness, or the intermediately specific misleading or aggressive, determinations depend.

A multi-level step procedure is not a novel approach in consumer protection Directives. Directive 93/13/EEC, of 5 April 1993, on unfair terms in consumer contracts also uses a similar mechanism, only with two steps. The use of notions and tests of an increasing level of generality and abstraction seem to respond to the desire to reconcile two potentially opposite interests. On the one side, to obtain a significant degree of legal certainty for those potentially subject to the new rules, so that they can obtain clear regulatory indications of some prohibited behaviours, that will allow them to mitigate the risk of regulatory non-compliance. On the other side, not to provide too easy and unsatisfactory -from the point of view of social welfare- safe-harbours for the traders, so to leave numerous loopholes in the more detailed regulations, through which firms could still exploit their superior position -in information, essentially- at the expense of consumers. As such, no a priori objection can be raised against these kinds of regulatory strategies. The building blocks of the different steps, though, could be well-chosen or infamous.

The general unfairness clause receives meaning via a double test. First, professional diligence of traders has to be determined, and the actual commercial behaviour of the individual trader has to be assessed against this standard. The violation of the standard is a pre-condition for a finding of unfairness (at the top level of the general unfairness concept). This exercise greatly reminds the observer of the negligence rule in Tort law, that sets legal standards of due care against which the actual care behaviour of tortfeasors is evaluated. In Law and Economics terms, the Hand formula -a shortcut for cost-benefit analysis of care and total accident costs- nicely explains how the negligence rule is to be understood from an economic perspective. 
It is a well-established result 33 in the economics of liability that negligence rules, if the due care standard is set optimally, induce the efficient behaviour in the population targeted by the rule. So, in this case, if the standard of professional diligence of traders is adequately set (either by legislators, by regulators or by Courts), the commercial actions of firms would be the optimal ones. The big caveat, as should be apparent, lies in the assumption that the standard of behaviour is adequately -optimally, in terms of social welfare- set.

Setting optimal standards is no easy task in any realistically imaginable situation. Several factors, however, can lead to think that this task would be particularly Herculean in this setting. These factors clearly point in the direction of expecting that it would be extremely unlikely that the determination of what constitutes professional diligence in the field of commercial practices will be just right in terms of the balance of costs -more care in communicating or otherwise interacting with consumers on the part of the firms- and benefits -eliminating the resulting harm to consumers from the different alternative ways of conduct- of the universe of commercial practices and actions available to firms. First, the mere heterogeneity of the agents involved (potentially all firms engaging in b2c commercial activities in the European market, and all European consumers) increases dramatically the complexity of the task: The optimal standard of behaviour, at least in theory, should be perfectly tailored to the characteristics of the specific agents involved, and the more heterogeneous the agents and the relevant circumstances, the harder is to tailor the standards. Moreover, given that in practice perfect tailoring is unfeasible, and some kind of average standard is required, which definitely implies some efficiency loss, the larger the diversity, the larger also the efficiency costs of averaging 34 . Firms engaging in commercial practices are extremely diverse. Some are huge, some small, some are solvent, some have no assets, some are established market leaders, some are fly-by-night operators ${ }^{35}$. To determine the professional diligence standards for all of them on the basis of a general formulation seems almost chimerical.

Second, the optimal determination of professional diligence standards in commercial b2c practices cannot be accomplished without looking at the harm resulting from the alternative feasible practices (including no practice at all). Art. 5.2 seems to cut off the professional diligence inquiry, in 5.2 (a), and the inquiry over harm, under the guise of material distortion of the economic behaviour of consumers, in art. 5.2 (b), as if both could be carried out independently. Economically, no optimal standard can be determined without having an estimate of the expected harm for each of the alternatives of conduct which may become the standard. And the

\footnotetext{
33 Already in J. P. BROWN, 'Toward an Economic Theory of Liability' (1973) 2 Journal of Legal Studies 323. The canonical treatment is S. SHAVELL, Economic Analysis of Accident Law (Cambridge (MA)-London: Harvard University Press, 1987).

34 On these issues of average versus individualized standards, see W. LANDES and R. POSNER, The Economic Structure of Tort Law (Cambridge (MA)-London: Harvard University Press, 1987).

35 In a recent paper, it has been shown that standards of care, both individually and at the level of an entire legal system, should optimally vary with the level of wealth or assets: J. GANUZA and F. GóMEZ, 'Optimal Negligence Rule under Limited Liability' (2004) Working Paper, Universitat Pompeu Fabra Department of Economics and Business, available at http:/ / papers.ssrn.com/sol3/papers.cfm?abstract_id $=563849$
} 
issue of harm in this context, built upon the average consumer test, presents problems of its own, on which more will be said later.

Third, Directive 2005/29 does not give any hints at how to understand and construct the professional diligence standard crucial for the first -or top- level of determination of the unfairness test. The likelihood that legislators, regulators and Courts in the different Member States may have radically divergent views upon the role and content of such standard, particularly in view of the diverse contexts in which the standard has to apply, is very high, thus heavily questioning the plausibility of a coherent solution. In order to effectively govern the behaviour of firms and effectively protect consumers the likely results of the unfairness test applied to commercial practices have to be anticipated, at least approximately, so that firms actually can plan their commercial strategies in accordance with the required standards. The lack of clues seriously undermines this possibility of anticipation, and with it the incentive effects of the unfairness test, at least at this abstract level of generality.

Finally, standards of behaviour in the commercial setting are notoriously difficult to establish. Legislators and Courts are no business experts, and this explains how in other areas of the Law, notably that of liability of managers, legal systems tend to use a hands-off approach, illustrated by, among others, the 'business judgement doctrine' ${ }^{\prime 36}$.

The second part of the top-level test is the material distortion of the economic behaviour of the average consumer whom the practice in question reaches, or to whom the practice is addressed. As has been already observed, the material distortion notion corresponds, broadly speaking, to the idea of effective and relevant harm to the consumer. The 'average consumer' concept would provide the way to circumscribe the population against which to assess the existence and level of harm. The finally approved text has eliminated from art. 2, containing the definitions, the one on 'average consumer' included in the Proposal. Recital (18) of the Preamble has kept the wording of the former definition, describing this construct as a consumer ' who is reasonably well-informed and reasonably observant and circumspect...', and expressly grounds the notion in the case law of the $\mathrm{ECJ}{ }^{37}$.

The notion of 'average consumer' remains, however, controversial ${ }^{38}$. From an economic perspective, several observations are pertinent. First, the notion is a composite, in the sense that it has no immediate real world correspondence. In reality there is no average consumer, just individual consumers each with his or her own endowment of information, attention, and set of beliefs and preferences. Optimally, harm -not just for compensation purposes, also for defining standards or other normative criteria- should be assessed also individually, taking into account

36 See S. BAINBRIDGE, 'The Business Judgement Rule as Abstention Doctrine' (2003) Law and Economics Research Paper Series, UCLA School of Law, available at http:/ / ssrn.com/abstract $=429260$

37 Case 210/96 Gut Springheide GmbH and Rudolf Tusky v Oberkreisdirektor des Kreises Steinfurt [1998] ECR 4657 (ECJ).

38 See HowELLS, note 28 above, 366-367. 
the specificities of each consumer. There are powerful reasons -unobservability by other agents, unverifiability by external authority, uncertainty, perverse strategic incentives for individualsthat explain the use of average benchmarks in lieu of individual ones ${ }^{39}$. I am convinced that these reasons keep much of their power in the context of setting the unfairness test.

Using averages, however, requires a clear definition of the population or variable range from which the average -or whatever other statistical concept- is drawn. This is somewhat obscure in Directive 2005/29, because what is the relevant population needs to be defined. One could think, true, that it is the targeted national -or regional, or local, depending on the reach of the practiceand/or product market what would provide the answer, because it would define the group of consumers at which the practice is directed (art. 5.2 (b) in fine). This impression is to a large extent neutralized by art. 5.3, which, for the purposes of offering extra protection to vulnerable consumers, qualifies the average consumer test in the following way: if a practice is likely to materially distort the economic behaviour only of a clearly identifiable group of consumers who are particularly vulnerable to the practice or the underlying product because of their mental or physical infirmity, age or credulity in a way which the trader could foresee, the practice should be assessed from the perspective of the average member of that group. It seems, then, that if it is necessary to clarify that the targeted public is the relevant population in cases of vulnerable consumers, it is legitimate to think that otherwise the population is not defined as targeted audience or group. How it is defined in other fashion is not apparent in the text of the Directive.

Moreover, as recital (18) of the Preamble makes clear, following the ECJ, the average consumer test is not a statistical test, but that Courts and authorities should exercise their own faculty of judgement to determine the typical reaction of the average consumer in a given case. But if it is not a statistical composite of how real individual consumers are and react, what is the average consumer? A normative aspiration? A moral claim? A social construct? An ad hoc determination based on policy or, worse, expediency to move the unfairness threshold up or down as desired by the decision-maker? From a Law and Economics perspective, harm to consumers from a commercial practice should be evaluated for the purposes of a determination of fairness or unfairness of the practice against the benchmark of how consumers really are and act, not how they could or should act, based on some external normative criterion. To take people as they are, and to use empirical techniques to know how they are, seem unavoidable requirements of economic analysis in this area.

The second level step distinguishes between misleading and aggressive practices. Within the first category Directive 2005/29 tackles in a differentiated way positive actions from firms, and omissions to inform. What amounts as a misleading action appears in art 6.1 (with a slightly aggravated form in 6.2). An action is misleading if it provides false information concerning some -defined in items (a) through (g)- elements of the transaction, or is deceitful for the average consumer, even if factually correct, concerning those same elements. In both cases (falsity and deceitfulness) it is necessary that the average consumer would take -or is likely that he or she

\footnotetext{
${ }^{39}$ A recent treatment of these issues in J. GANUZA and F. GómEZ, 'Caution, Children Crossing! Heterogeneity of Victim's Cost of Care and Negligence' (2005) 1 Review of Law and Economics.
} 
would- a regrettable transactional decision as a consequence of the exposure to the misleading practice. Although located at the end of art. 5.3, the remark on the fact that it is a common and legitimate advertising practice to make exaggerated statements or statements which are not meant to be taken literally, also belongs, logically, to the test on misleading actions.

The basic features of such a test of misleading action follow arts 2.2 and 3 of Directive 84/450/EEC, of 10 September 1984, concerning misleading and comparative advertising. Some though not all- of those features seem to nicely correspond with implications of the economic analysis of advertising ${ }^{40}$. The idea that the literal meaning, and even the interpretation, of a communication from firms, should not determine a finding of deception, is one. That a communication should not be misleading if it does not generate beliefs ${ }^{41}$ in consumers, and that they act upon such beliefs in a manner detrimental to their own interests -harmfulness is an important element of deception in this field-. That correcting communications from firms to avoid misleading or deceiving consumers is not free, and that the costs of correction can be very high.

The list of elements to determine falsity or misleading character, however, seems to present serious problems. The idea of having a sole set of dimensions of the interaction between firm and consumer, that is uniformly relevant for a finding of unfairness is unnecessarily rigid. Each market and each product can be very different in this respect. For instance, if a product feature is a search characteristic (search can make consumers informed about it) the need to rely on information from the producer, and on the legal system to deter deception, is much lower. When the feature is an experience characteristic (consumers will become informed after consuming the good) the case is intermediate, and it is when facing credence characteristics (those that even after consumption are not ascertainable by the consumer) that the likelihood and risks of deception, and the potential benefits of legal intervention against it, are highest. The catalogue of transactional dimensions contained in art. 6.1 of Directive 2005/29 is too undiscriminating. The list is also exceedingly exhaustive and detailed, given its validity for the entire universe of markets. Some of the elements included can hardly play a major role in most markets for goods and services, and a shorter and non-closed list might have been a more attractive strategy.

Art. 6 also contains an aggravated instance of misleading action, when, assuming the negative impact upon the behaviour of the average consumer, and without falsity or deceitfulness being established, there is confusion with the products, brands or trademarks of competitors, or when firm commitments in expressly declared binding codes of conduct are ignored or violated. The

\footnotetext{
40 An excellent technical survey of the economic literature on advertising, in K. BAGWELL, 'The Economic Analysis of Advertising' (2003) Working Paper, Columbia University Department of Economics, available at http:// www.columbia/ kwb8/adchapterPost082605.pdf. With a direct policy or legal orientation, see also R. CRASWELl, 'Regulating Deceptive Advertising: The Role of Cost-Benefit Analysis', (1991) 64 Southern California Law Review 550; CALFEE, note 18 above; Rubin (2004), note 7 above.

41 If no one believes a statement in a commercial communication, however false or misleading it may be, there is no need to engage the expensive machinery of regulatory agencies and the Law to correct it. The same applies if a statement is believed, but no one would act upon such a false belief. This is the rationale for allowing, without much hesitation, exaggerations or even outright lies in advertising, when they are discernible by every person in the public.
} 
justification for this special provision seems obscure, and the grounds for a somewhat separate test do not appear to be transparent and compelling enough.

Finally, and strangely placed in art. 12 on Courts and administrative authorities, Directive 2005/29 displays a rule on the burden of proof on the truthfulness of factual claims made in commercial practices, or as it is usually called in the Law of misleading advertising, on the substantiation of claims in advertising. The rule forces Member States to confer power on Courts or regulatory agencies to require firms to provide evidence on the accuracy of factual claims in relation to a commercial practice. This imposition of the burden of presenting evidence ${ }^{42}$ is, however, qualified by the subjection to the judgement of the appropriate authority on whether that allocation of the burden of proof is the adequate one in the circumstances.

Such a pragmatic view on the burden of proof of substantiation of claims seems reasonable from an economic perspective. The efficiency goal of allocating the burden of proof in this matter is to minimize the harm from two types of errors ${ }^{43}$. Type I errors (false positives) are errors caused by allowing as fair a claim that is factually false. Type II errors (false negatives) are errors caused by not allowing -making it a misleading action- a claim that is factually true. The goal would be to minimize the sum of the negative consequences from both types of errors. In theory, none of them should be considered more or less serious than the other. The outcome depends on the harm resulting from each of them, and the prior probabilities of each kind of error. For instance, if a false positive is very harmful (maybe because of grave effects on the health of consumers) then avoiding Type I errors is very important. The reverse is true if avoiding a certain communication or practice would deprive consumers of an important new product or use of a product. Thus, no rigid allocation of the burden of substantiation achieves the optimal solution all the time. Sometimes, depending on the circumstances and the relative social importance of one or the other error, it is best to impose the burden of showing the accuracy of claims on the firm. In other circumstances, when the balance of social costs changes, it is best to impose the burden of disproving the claim on the consumer or agency challenging the commercial practice. No simple allocation rule is universally desirable. As in other instances, it is cost-benefit analysis which should lead the way.

Art. 7 of Directive 2005/29, still within this level of misleading practices, regulates misleading omissions, a notion that is substantially new with respect to Directive $84 / 450$. The idea of a misleading omission determining a finding of unfairness is more disturbing, in economic terms, than what happens with positive misleading actions.

First, because it transpires some distrust on the appropriateness of the level of consumer information prevailing in consumer markets. In fact, we should not think that consumer markets

\footnotetext{
42 For an analysis of the distinction between burden of production and burden of persuasion, see B. HAY and K. SPIER, "Burdens of Proof in Civil Litigation: An Economic Perspective' (1997) 26 Journal of Legal Studies 413; R. POSNER, 'An Economic Approach to the Law of Evidence' (1999) 52 Stanford Law Review 1477.

${ }^{43}$ See RubiN (2004) note 18 above, 7-8.
} 
are entirely dominated by imperfect information. Even if we abstract from legal constraints and requirements to this effect, the level of information provided by and at the disposal of market participants in consumers' markets is by no means negligible ${ }^{44}$. Consumers acquire information about relevant characteristics and variables affecting the transactions on goods and services by several means. In some cases, they can acquire information by direct observation. In others, by learning through repeat purchase and consumption. They can also get information about relevant aspects from third parties, be they people known to them, or independent private and public sources.

Producers themselves are major providers of information in consumers' markets. Through labels, product descriptions, and contract information firms communicate significant amounts of information to consumers on goods and services. Of course, advertising plays a key role in transmitting information ${ }^{45}$ on the existence, characteristics, prices and other determinants of market transactions. And not only the so-called 'informative' advertising has this positive informational role. Even advertising apparently devoid of any significant informational content (like celebrity endorsement of a product, say), is able to convey to consumers valuable signals about the level of quality or other important features of the transaction: Advertising, and the reputation that is usually associated with it, are extremely powerful market mechanisms to effectively signal consistent levels of quality to consumers, particularly in markets for experience goods ${ }^{46}$.

More surprisingly, market forces can, under some conditions, induce producers to disclose even unfavourable information to consumers or, more generally, to the other party in a prospective transaction. In what is one of the more striking results of the economics of information, it can be shown that, when the private information in possession of the seller is verifiable (that is, ex post it can be determined if disclosure of information was truthful), and the consumer knows that the seller has private information (though not its content, or else it would not be private information of the seller), the seller will voluntarily reveal the information even if it is unfavourable (for instance, that the quality of her product is below average). This unravelling result stems from the fact that, given the two assumptions just mentioned, consumers expects from all silent sellers the worst possible news concerning the content of the private information. Sellers whose private information is best would voluntarily disclose it, and so would set in motion a continuous process of revelation by the decreasingly good-news sellers, until only that with the worst private information (say, the worst quality) is left alone without disclosure. And consumers would

44 A recent review of instruments increasing information available to consumers in T. WEIN, 'Consumer Information Problems - Causes and Consequences', in S. GRUNDMANN, W. KERBER, and S. WEATHERILL (Editors), Party Autonomy and the Role of Information in the Internal Market (Berlin-New York: Walter de Gruyter, 2001$) 80$.

45 It must be emphasized that the goal of advertising for firms is not to inform, but to persuade to buy, and if there is no possibility of persuasion, firms would not advertise. Consumers, aware of this objective, tend to be generally untrustful of advertising, though they can deduce significant amounts of information from it.

46 On this warranty function of advertising, see F. GómEZ, 'The European Directive on Consumer Sales: An Economic Perspective', in S. GRundmann and C. M. BIANCA (editors), EU Sales Directive Commentary, (AntwerpNew York: Interscientia, 2002), and literature cited therein. 
actually observe that their expectations are met: Only the worst private information remains undisclosed, and the rest is voluntarily revealed ${ }^{47}$. Art. 7 of Directive 2005/29 seems to be entirely unaware of these incentives to provide even negative information, when it is verifiable and fraud is sanctioned. This would imply that regulatory effort to increase information for consumers should emphasize the battle against fraud, and not so much overload firms with obligations to disclose certain items of information determined externally by the regulator, which may be irrelevant, or even worse, unwanted ${ }^{48}$.

A third important shortcoming lies in the fact that the Directive seems to have ignored the problems of information overload for consumers. Increasing the amount of information (for instance, additional risks possibly deriving from the use of a given product) may in fact confuse consumers, by making them disregard or downplay the overall benefits from it ${ }^{49}$. That is, increasing the amount of information in commercial communication can be costly, not just for the firm, but also socially. It is true that art. 7.3 indicates that the intrinsic limitations of space and time of the medium used to communicate with consumers should be taken into account in assessing where there was a misleading omission. These constraints should indeed play a role, because they affect directly firms' costs in providing additional information. But it is not enough. Consumers' constraints in processing the additional information (which may be somewhat correlated with those intrinsic limitations, but far from perfectly) should also be included in the cost-benefit analysis of adding to the informational content of the communications.

Fourth, there does not seem to be awareness in the Directive's provisions on omissions, that information in commercial communication is necessarily incomplete, and that attempting to reach complete informational content may well be counterproductive, because the real alternative for firms if they are forced to add endless supplementary information may be simply to discontinue the practice, an outcome which may be worse than incomplete information commercial practice, because consumers will loose all information, however incomplete, they may have gotten without the legal prohibition or intervention ${ }^{50}$.

\footnotetext{
47 The unravelling result was developed by S. GROSSMAN and O. HART, 'Disclosure Laws and Takeover Bids' (1980) 35 Journal of Finance 323; P. Milgrom, 'Good News and Bad News: Representation Theorems and Applications' (1981) 12 Bell Journal of Economics (1981) 380; S. GROSSMAN, 'The Informational Role of Warranties and Private Disclosure of Product Quality' (1981) 24 Journal of Law and Economics 461. A less technical presentation with applications to various fields of the Law, in D. BAIRD, R. GERTNER and R. PICKER, Game Theory and the Law, (Cambridge (MA)-London: Harvard University Press, 1994) 89 following; R. GERTNER, 'Disclosure and unravelling', in P. NewmAn (editor), The New Palgrave Dictionary of Economics and the Law, vol. I, (London: MacMillan, 1998) 605. Empirical studies have found clear evidence of voluntary disclosure and unravelling. For instance, A. MATHIOS, 'The Impact of Mandatory Disclosure Laws on Product Choices: An Analysis of the Salad Dressing Market' (2000) 43 Journal of Law and Economics 658-660, shows how the unobservable information (fat content) concerning salad dressings is subject (albeit not completely) to the unravelling effect, by which almost all of the low-fat producers voluntarily disclose the fat content whereas the high-fat ones remain silent.
}

48 See P. Bolton and M. DewATRIPONT, Contract Theory (Cambridge (MA)-London: MIT Press, 2005) 176.

49 See CRASWELL (1991), note 40 above, 568, citing empirical studies on this point.

50 See CALFEE, note 18 above, 96-106. 
All in all, the rules on misleading omissions appear to be too intrusive on the market forces at play in the provision of information in the marketplace, and too disdainful of the costs of completing information for consumers. The list of product and transaction features that are to be regarded as material when there is an invitation to purchase $\mathrm{e}^{51}$ is also exceedingly exhaustive and detailed, given its universal reach for all goods and services. Again, a shorter and open list might have been more advisable from an economic perspective. Particularly excessive and Eurocentered seems the rule in art. 7.5 of the Directive, that considers all informational requirements already imposed by Community Law as material for a finding of misleading omission. A noninsignificant part of these requirements are of contractual or pre-contractual nature, and to set the same constraints for all commercial actions, as art. 7.5 does, seems inadequate.

Arts. 8 and 9 deal with aggressive practices. The general notion is based on preventing the use of harassment, coercion, physical force and undue influence in commercial actions, to the detriment of consumers. Letting aside undue influence for a moment, there can be little disagreement with this sort of regulation. Harassing, coercive and violent behaviour all seriously and obviously reduce social welfare and should be banned from commercial activities, as well as from other social interactions. Undue influence, defined in art. 2 (j) as '...exploiting a position of power in relation to the consumer as to apply pressure, even without using or threatening to use physical force, in a way which significantly limits the consumers' ability to make an informed decision'. Although it is not entirely clear, there may be a suggestion here of the notion of inequality of bargaining power. If one thinks of the economic substance of the interaction, when it takes place under perfect information, the idea of inequality of bargaining power between firms and consumers assumes that a transaction between a large firm and a small consumer will imply a reduction in quality of the relevant transaction variables, including contractual rights and obligations. But the truth is that the fact, for instance, that we have a large monopolistic firm contracting with a minuscule (in economic terms) consumer, does not by itself raise concerns and suspicions about the terms of the transaction that consumer protection Law or the Law of commercial practices is well-placed to address and eventually to improve upon. Improvements, if such is the case, might come from the side of competition Law, but these will affect price paid and quantity transacted by all consumers, and not the commercial practices or the terms of the individual contract.

The factors listed in art. 9 seem more to the point: Threatening or abusive language and behaviour seem natural examples of the kind of conduct one would want to deter. The same happens by artificial situational monopolies such as creating onerous or disproportionate noncontractual barriers to exercise rights under the contract, or to vote with the feet and take business elsewhere [art. 9 (d)]. Not differently, it also seems economically undesirable to use general commercial practices ${ }^{52}$ that exploit situations of misfortune or exercise duress on consumers [art. 9 (c) and (e)].

\footnotetext{
51 A distinction from general commercial communication that is somewhat artificial, if one reflects on the persuasive goal of all commercial communication.

52 Contracts individually negotiated may require a more nuanced solution, given the economic complexity of the Law of duress. See S. SHAvELL, 'Contracts, Holdup and Legal Intervention' (2005) Working Paper, John M. Olin
} 
Finally, turning to the black list of specifically prohibited practices in Annex I, an exhaustive analysis would require a paper of its own. The list includes obviously inefficient practices, such as verifiably false statements, or abusive or harassing behaviour, but it also brings in practices (bait advertising, pyramids) which would require a deeper consideration of costs and benefits. In general, all constraints on price information should be reduced to a minimum, and looked with great suspicion ${ }^{53}$.

\section{Conclusion}

The present paper is a preliminary analysis of Directive 2005/29, specially of the rationales, scope, and major substantive policy options in the determination of unfairness, that underlie this new legislative development in European Consumer Law -and in Business Law generally. More detailed theoretical analysis, and also extensive empirical inquiry on the effects of the new rules on the future actions of firms in the marketplace vis-à-vis consumers are needed. The economic case for many of this new set of regulatory constraints on commercial practices in Europe, however tentative the judgement as it now stands, is not strong, or at least not strong enough.

\footnotetext{
Center for Law, Economics and Business, Harvard Law School, available at http:/ / papers.ssrn.com/sol3/papers.cfm?abstract_id=716901

53 See RUBIN (1991), note 7 above; RUBIN (2004), note 7 above, 3-4.
} 


\section{References}

K. BAGWELL, 'The Economic Analysis of Advertising' (2003) Working Paper, Columbia University Department of Economics, available at http://www.columbia/ kwb8/adchapterPost082605.pdf

S. BAINBRIDGE, 'The Business Judgement Rule as Abstention Doctrine' (2003) Law and Economics Research Paper Series, UCLA School of Law, available at http:/ / ssrn.com/abstract $=429260$

D. BAIRD, R. GERTNER and R. PICKER, Game Theory and the Law, (Cambridge (MA)-London: Harvard University Press, 1994) 89

O. BAR-GILl, 'Seduction by Plastic' (2004) American Law \& Economics Annual Meeting Papers, available at http://law.bepress.com/alca/14th/art12

H. BeAles, R. CRASWell, and S. SAlop, 'The Efficient Regulation of Consumer Information' (1981) 24 Journal of Law and Economics 491

A. BEATER, 'Europäisches Recht gegen unlauteren Wettbewerb- Ansatzpunkte, Grundlagen, Entwicklung, Erfoderlichkeit' (2003) ZEuP 11

P. BOLTON and M. DEWATRIPONT, Contract Theory (Cambridge (MA)-London: MIT Press, 2005) 176

J. P. BROWN, ‘Toward an Economic Theory of Liability' (1973) 2 Journal of Legal Studies 323.

C. BUSCH, 'Ein europäischer Rechtsrahmen für das Lauterkeitsrecht? Der Vorschlag der Europäischen Kommission für eine Richtlinie über unlautere Geschäftspraktiken' (2004) European Legal Forum 91

J. E. CALfEE, Fear of Persuasion. A New Perspective on Advertising and Regulation (Monnaz: AgoraAEI 1997)

R. H. COASE, The Firm, the Market and the Law (Chicago: University of Chicago Press, 1991)

H. COLLINS, 'EC Regulation of Unfair Commercial Practices', in H. Collins (editor) The Forthcoming EC Directive on Unfair Commercial Practices (The Hague/London/New York: Kluwer Law International, 2003) 1

R. CRASWELL, 'Regulating Deceptive Advertising: The Role of Cost-Benefit Analysis', (1991) 64 Southern California Law Review 550

---, 'Passsing-On the Costs of Legal Rules: Efficiency and Distribution in Buyer-Seller Relationships' (1991) 43 Stanford Law Review 361

---, '"Compared to What?" The Use of Control Ads in Deceptive Advertising Litigation' (1997) 65 Antitrust Law Journal 757 
S. Della Vigna, and U. MALMENDIER, 'Contract Design and Self-Control: Theory and Evidence' (2004) 119 Quarterly Journal of Economics 353

J. GANUZA and F. GómEZ, 'Optimal Negligence Rule under Limited Liability' (2004) Working Paper, Universitat Pompeu Fabra Department of Economics and Business, available at http://papers.ssrn.com/sol3/papers.cfm?abstract_id=563849

---, 'Caution, Children Crossing! Heterogeneity of Victim's Cost of Care and Negligence' (2005) 1 Review of Law and Economics

R. GERTNER, 'Disclosure and unravelling', in P. NEWMAN (editor), The New Palgrave Dictionary of Economics and the Law, vol. I, (London: MacMillan, 1998) 605

F. GómEZ, 'The European Directive on Consumer Sales: An Economic Perspective', in S. GRUNDMANN and C. M. BIANCA (editors), EU Sales Directive Commentary, (Antwerp-New York: Interscientia, 2002)

L. GONZÁLEZ-VAQUÉ, 'La Directiva 2005/29/CE relativa a las prácticas comerciales desleales en materia de protección de consumidores' (2005) 18 Derecho de los negocios 5

S. GROSSMAN, 'The Informational Role of Warranties and Private Disclosure of Product Quality' (1981) 24 Journal of Law and Economics 461

--- and O. HART, 'Disclosure Laws and Takeover Bids' (1980) 35 Journal of Finance 323

S. GRUNDMANN, 'Verbraucherrecht, Unternehmensrecht, Privatrecht - warum sind sich UNKaufrecht und EU-Kaufrechts-Richtllinie so ähnlich?', (2002) 202 AcP , 40

---, 'European Contract Law of What Colour?' (2005) 2 European Review of Contract Law 184

---, W. KeRBER, and S. WEATHERILL, 'Party Autonomy and the Role of Information in the Internal Market - an Overview', in S. GRUNDMANN, W. KERBER, and S. WEATHERILL (Eds.), Party Autonomy and the Role of Information in the Internal Market, (Walter de Gruyter, Berlin-New York: Walter de Gruyter, 2001) 7

G. HAdfield, R. Howse, and M. TReBILCOCK, 'Information-Based Principles for Rethinking Consumer Protection Policy' (1998) 21 Journal of Consumer Policy, 131

J. D. HANSON, and D. A. KYSAR, 'Taking Behavioralism Seriously: The Problem of Market Manipulation' (1999a) 74 New York University Law Review 630

---, 'Taking Behavioralism Seriously: Some Evidence of Market Manipulation' (1999b) 112 Harvard Law Review 1420

B. HAY and K. SPIER, "Burdens of Proof in Civil Litigation: An Economic Perspective' (1997) 26 Journal of Legal Studies 413 
L. HeInZERLING, 'Regulatory Costs of Mythic Proportions' (1998) 106 Yale Law Journal 1981

G. Howells, 'The Scope of European Consumer Law' (2005) 3 European Review of Contract Law 360

R. HYNES, and E. POSNER, 'The Law and Economics of Consumer Finance' (2002) 4 American Law and Economics Review 194

C. Jolls, C. SunsteIN, and R. ThALeR, Behavioral Law and Economics (Cambridge: Cambridge University Press, 2002)

L. KAPLOW, and S. SHAVELL, Fairness versus Welfare (Cambridge (MA)-London: Harvard University Press, Cambridge, 2003)

W. LANDES and R. POSNER, The Economic Structure of Tort Law (Cambridge (MA)-London: Harvard University Press, 1987)

A. MATHIOS, 'The Impact of Mandatory Disclosure Laws on Product Choices: An Analysis of the Salad Dressing Market' (2000) 43 Journal of Law and Economics 658

H.-W. MicKLITZ, 'A General Framework Directive on Fair Trading', in H. Collins (editor) The Forthcoming EC Directive on Unfair Commercial Practices (The Hague/London/New York: Kluwer Law International, 2003) 43

P. Milgrom, ‘Good News and Bad News: Representation Theorems and Applications' (1981) 12 Bell Journal of Economics (1981) 380

T. MURIS, 'The Federal Trade Commission and the Future Development of U. S. Consumer Protection Policy' (2004) George Mason University School of Law, Law and Economics Working Paper Series, 04-19, 7-16 at http://ssrn.com/abstract_id=545182

R. POSNER, Economic Analysis of Law, 5 $5^{\text {th }}$ edition (New York: Aspen Publishers, 1998) 408

---, 'An Economic Approach to the Law of Evidence' (1999) 52 Stanford Law Review 1477

J. RACHLINSKI, 'The Uncertain Psychological Case for Paternalism' (2003) 97 Northwestern University Law Review 1165

I. RAMSAY, 'Consumer protection', in P. NEWMAN (editor), The New Palgrave Dictionary of Economics and the Law, vol. I (London: MacMillan, 1998) 413

K. RIESENHUbER, 'System and Principles of EC Contract Law' (2005) 3 European Review of Contract Law 296

P. RubIN, 'The Economics of Regulating Deception' (1991) 10 Cato Journal 667

---, 'Regulation of Information and Advertising' (2004) Emory School of Law, Law and Economics Research Paper Series, WP No. 04-05, 6 at http:/ / ssrn.com/abstract $=498683$ 
R. SCHECHTER, 'The Death of the Gullible Consumer: Towards a More Sensible Definition of Deception at the FTC' (1989) University of Illinois Law Review 571

S. SHAVELL, Economic Analysis of Accident Law (Cambridge (MA)-London: Harvard University Press, 1987)

---, 'Contracts, Holdup and Legal Intervention' (2005) Working Paper, John M. Olin Center for Law, Economics and Business, Harvard Law School, available at http:/ / papers.ssrn.com/sol3/papers.cfm?abstract_id=716901

J. STUYCK, E. TERRYN, and T. VAN DYCK, 'La proposition de directive "pratiques commerciales déloyales": quel marché unique pour le consommateur?' (2003) Revue européene de droit de la consummation 239

Symposium issue 'Cost-benefit Analysis: Legal, Economic, and Philosophical Perspectives' (2000) 29 Journal of Legal Studies

T. WEIN, 'Consumer Information Problems - Causes and Consequences', in S. GRUNDMANN, W. KERBER, and S. WEATHERILl (Editors), Party Autonomy and the Role of Information in the Internal Market (Berlin-New York: Walter de Gruyter, 2001) 80

D. WeISBACH, 'Taxes and Torts in the Redistribution of Income', (2002) University of Chicago Law School, John M. Olin Program in Law \& Economics, Working Paper No. 148 